International Journal of English Literature and Social Sciences
Vol-6, Issue-6; Nov-Dec, 2021

Peer-Reviewed Journal

\title{
Andrew's Wall-E Reflection: Technology a threat to Humanity
}

Ms. Vasudha L.

M.A. English, PG from a College Affiliated to University of Calicut, Kerala, India.

Received: 28 Sep 2021; Received in revised form: 29 Oct 2021; Accepted: 07 Nov 2021; Available online: 13 Nov 2021

(C2021 The Author(s). Published by Infogain Publication. This is an open access article under the CC BY license

(https://creativecommons.org/licenses/by/4.0/).

Abstract - The entire landmass is endowed with surplus flora, fauna, and other natural resources. But now we live in a world where technology has superimposed on nature causing exploitation of resources because of human greed. Wall-Eby Andrew Staton is one such movie that depicts the situation of earth and the consequence faced by human beings. It encompasses several warnings and dreads for the environment. The paper aims to look at the film as a reflection of the present scenario where overuse technology has made human beings lazy and has lost compassionate feelings for one another.

Keywords-Environment, exploitation, humanity, technology, threat.

\section{INTRODUCTION}

The film has a powerful bond within human culture and it can be considered as a reflection of society. In this era, films are used as a productive tool for raising awareness and educating us about environmental issues. This film encourages its viewers to become more sensitive, protective and to shape human-nature relationships and environmental issues. Humans have made the environment polluted and unsafe for the existence of life and these issues are portrayed through the film Wall-E.

Wall-E is a 2008 American computer-animated science fiction film produced by Pixar Animation studio for Walt Disney pictures directed by Andrew Staton. Staton is an American film director and his works include Finding Nemo and Wall-E. Wall $-E$ is a science fiction film about a lonely robot whose primary mission is to clean up abandoned and polluted earth. The film criticizes consumerism, corporatism, waste management, human environmental impact, and obesity. Wall-E (Waste Allocation Load lifter, Earth class) is a robot who has developed emotions and is the only robot of his kind shown to be still functioning on earth. He is a small mobile compactor box with all-terrain trends, three fringed shovel hands, binocular eyes, and solar cells for power. He is working to fulfill his directive to clean up the garbage. Another character in the film is Eve (Extraterrestrial Vegetation Evaluator), a glossy robot whose directive is to locate vegetation on earth and verify habitability. Wall-E is a dystopia set around 700 years in the future. It is a tale of the present consumption-driven societies, where no one cares about the damage-causing to nature and threatening on our survival of the planet.

\section{TRANSGRESSION OF TECHNOLOGY AS IN WALL-E}

The first half of the movie portrays the impact of technology on human beings and in the end, humans on the Axiom struggled to resist the technology. In the movie, people have become so dependent on technology that their only experience and communication are via technology. People are exploiting technology for their benefit and eventually going to end up with our society for the worse. Most of the relationships maintained currently are at some degree mediated and maintained through electronics whether it is texting, phone calls.

Technology and human life cannot be separated; society has a cyclical dependence on technology. In the very first scene, stars, galaxies, and the beauty of space are portrayed zooming in on trash-covered polluted green earth with billions of artificial satellites orbiting around it and no sign of life. The bleak and desolate scene of the earth depicts that humans have destroyed the planet with waste and it is no longer inhabitable. The barren land with large garbage heaps portrays that overindulge of these electronic gadgets and the invention of new electronic 
devices has resulted in a large number of E-wastes leading humanity to decide to flee uninhabitable earth.

Technology provided the solution to inhabitable earth in the form of a luxury spaceship by Buy $n$ Large Corporation (BnL), the Axiom. The humans in the movie are citizens of the Executive starliner the Axiom. They are morbidly obese, float around in hoverchairs. All humans in the spaceship are obese, with very short fingers, no neck, and legs too short. From this, it is very clear that technology has played a major role in their current state because technology is so advanced that there is a machine to do everything for them. The human in the Axiom has become weak-willed, indolent, and lazy. After seven hundred years of adrift humans have grown too bloated to walk and lazy to think and they never exercise, and if they happen to fall off their hovering chairs, they thrash around like babies until a robot helps them up. They watch television all day long and can barely read. It is more like kids in society who have replaced exercise and outdoor games with watching television and playing video games.

For another instance where the captain of the ship forgets to give the morning announcement, and then he suddenly rewinds the time and makes everything normal like early morning and gives his announcement. This is to portray that the technology has become so advanced that even time has come under of human beings. Humans around the Axiom are speaking to each other through the use of technology and their face is always on the screen. They are not even aware of the human in the chair next to them. This is similar to the present situation of our society. People of this generation usually do not have any face-to-face interaction with neighbours. But they would be friends on social media or they might be chatting through any online platform but they will not be able to recognize each other even if they are staying nearby. Wall-E and Eve the two robots are enjoying outside the ship enjoying, and actual humans are unaware of the happiness or enjoyment outside the world of technology. In the Axiom, real owners of the earth are spending their days sipping meals out of cups and enjoying the epitome of sedentary lifestyles. After hundred years of living in space not having to move muscle, humans have virtually converted themselves into couch potatoes.

Advancement in technology has reduced the thinking capacity of human beings and has molded them into the futile fellow. But not too far the humans in this world would be similar to that of the ones depicted in the movie. Wall-E is a warning and the scenario of that movie should serve as a huge red flag for what we are heading for.

\section{HUMANNESS: WALL-E AND EVE}

In Wall-E, the robots are more emotional and intelligent beings than the humans and the film tries to portray that the humans are blissfully unaware of their surroundings. The use of sound in the film shows that the robots have become more human than biological humans. Wall-E makes the typical human erotic whistle when he picks up a bra from the trash dump. Later on, Eve sneezes. Robots do not sneeze; these are certain actions or feelings which can be seen only in living creatures, not in machines. Wall-E listens to music and collects the object that he believes and holds the value.

In this movie love story between the two robots turns out to be deeply human and the biological humans in the Axiom do not have any kind of feelings or emotions, they even do not have face-to-face interaction. The love story between Wall-E and Eve is quite touching in the middle of the story when Eve becomes inert after capturing the green plant and in the end, Wall-E gets damaged resulting in the loss of memory when Eve realizes his love towards her. They risk their lives for each other as well as to save humanity. Even though the use of verbal language is less between hero and heroine, the relationship plays out through acts of kindness, simple, gestures and self-sacrifice. In the case of humans in the Axiom, they do not know the value of love or relationship because they do not have a notion towards humanely feeling or affection, and robots are imbibed with such individuality of the creator.

Wall-E and Eve even though they are robots assigned with certain work they have acquired almost all compassionate feelings than the actual humans in the Axiom. The irony of the movie is that robots, the mechanical and inanimate objects are the ones that have developed intimacy, relationship, touch, feeling, compassion and empathy. And the people who are supposed to have these traits and characteristics have been lost in technology and consumerism.

\section{CONCLUSION}

This film represents a dystopian community, the future of earth hidden behind a sweet love story between two robots. It poignantly portrays how humans are harming the earth and what they can expect in the future. It also shows how humans have lost their humanity by being over-dependent on technology. If we do not try to resist the overuse of technology one day our earth would result like the one depicted in Wall-E and may prove to be our executioner. 


\section{REFERENCES}

[1] Davis Larry. "Technology Prevents Humans from Thinking"', Film tank.17 November2009,www.filmtank.org/forum/filmdevelopment/films 224-wall-e

[2] Freedman Carl. Critical theory and science fiction, Wesleyan UP, 2000.

[3] Poon Nelson, "Reel Snacks: Wall-E", sunsetmedia wave, 2 August 2016, Sunsetmediawave.org/2017/08/reel-snackswall-e.

[4] Roberts, Adams. Science Fiction. Rout ledge books, 2006.

[5] Stanton, Andrew, director. Wall-E. Walt Disney Studios Motion Pictures. 2008.

[6] Technology role in Wall-e, Glassman blog, 26 November2011,www.cbersin/wordpress.com/2011/11/26/t echnology role-in-wall-e 